\title{
I am an igqirha (healer): phenomenological and experiential spiritual journey towards healing identity construction
}

\author{
Eu sou igqirha (curadora): jornada espiritual fenomenológica e experiencial \\ rumo à construção de uma identidade de cura
}

Lily Rose Nomfundo Mlisal

ABSTRACT

\begin{abstract}
Traditional healers are acknowledged within their communities as possessing special insight, intuition knowledge and skills to connect and converse with the universe better than an ordinary person. African religions are endowed with a wide variety of traditional healers and healing practices, using diverse healing practices, symbolisms and interpretations relevant to the contextual setting of their cultures. Rooted in that diversified rich ecological heritage of the indigenous religions, are unique personal spiritual journeys that depict individual phenomenological and existential ways of constructing meaningful special spiritual healing identities. Healing identities are created and manifested in different socio-cultural, physical and spiritual abundant sacred spaces travelled by an initiate. This is an inborn gift from ancestors. The spiritual journey is abundantly infested by crisis and requires resilience, passion and faith. I give my personal phenomenological spiritual life journey in the traditional and spiritual quest for a holistically construed healing identity and proper individuation. The journey encompasses various stages with differentiated growth, maturity and competences to be acquired. The objective for this narrative is many fold. It is a response to various individual respondent experiences, questions and inquiries that I always receive from the conference audiences and unique feedback narratives from others who are either in the confusion stage or denial stage, yet they are aware they have a calling to accept. Ukuthwasa journey is briefly discussed and the historical ontology of ukuthwasa is mapped up. The discussion addresses the responses expected as evidence based results to confirm the reality of ukuthwasa and its value to the self, family and community at large. In conclude by highlighting, my own revelations and reflections on what could be done and how I finally achieved my healing identity and its relation to the universe at large.

I am a fully-fledge trained igqirha, teacher, nurse and pastor. I practise as a Clinical psychologist and I have founded a prophesized church, a dream I had in 2001. I am also a founder of a community project for rural development at my village. All these achievements were shown to me by dreams and I followed my dreams under very challenging circumstances. I am from a family with a rich lineage of healers from both my paternal and maternal side, yet both became staunch Christian converts and ignored the cultural rites. To become a healer was not easy.
\end{abstract}

Key Words: training stages, igqirha, Xhosa, ukuthwasa, iphehlo, calling, healing identities

\footnotetext{
${ }^{1}$ Lily Rose Nomfundo Mlisa is a practising Clinical Psychologist, Queenstown, Eastern Cape Province, South Africa. Qualifications: Doctor of Philosophy-African Studies, Free State University; MA-Clinical Psychology, University of Port Elizabeth; MA-Public Health Science, and BA Hons- Theology at University of Fort Hare. BA: Psychology and Anthropology; BA Hons - Psychology and BA -Nursing Science, all in UNISA. BA: Nursing Science : UNISA. Currently : Research Fellow -University of Fort Hare and Independent Researcher and Director: Tsengiwe Development and Research Centre; Cala, Eastern Cape South Africa. Article received on 10/18/2019 and accepted on 11.20.2019. Contact: lillymlisa@ gmail.com
}

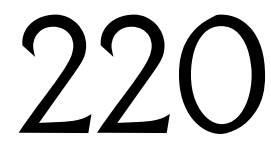


Curadores tradicionais são reconhecidos dentro de suas comunidades como possuidores de visão especial, conhecimento intuitivo e habilidades de se conectar e conversar com o universo melhor do que uma pessoa comum. Religiões africanas são dotadas de uma variedade ampla de curadores e práticas de cura tradicionais, usando diversos simbolismos, práticas e interpretações relevantes para a configuração contextual de suas culturas. Enraizadas nessa herança ecológica rica e diversificada das religiões indígenas estão as jornadas espirituais pessoais que retratam modos individuais fenomenológicos e existenciais de construir identidades especiais de cura espiritual plenas de sentido. Identidades de cura são criadas e manifestadas em diferentes espaços sagrados sócio-culturais, físicos e espiritualmente abundantes percorridos por um iniciado. Isto é um dom inato dos ancestrais. A jornada espiritual é abundantemente infestada pela crise e requer resiliência, paixão e fé. Eu ofereço minha jornada pessoal de vida espiritual e fenomenológica na busca tradicional e espiritual por uma identidade de cura construída holisticamente e por uma individuação adequada. A jornada abrange vários estágios com diferenciados crescimento, maturidade e competências a serem adquiridas. $O$ objetivo desta narrativa é múltiplo. $E$ uma resposta a várias experiências de pessoas com que me correspondo, questões e indagações que eu sempre recebo nas conferências e audiências e narrativas singulares compartilhadas por outros que estão tanto no estágio da confusão quanto no da negação, e ainda assim estão conscientes de terem um chamado a ser aceito. A Jornada Ukuthwasa é discutida brevemente e a ontologia histórica de ukuthwasa é mapeada. A discussão aborda as respostas esperadas como resultados baseados em evidência para confirmar a realidade de ukuthwasa e seu valor para o si-mesmo, para a família e para a comunidade em geral. Para destacar como conclusão, narro minhas próprias revelações e reflexões sobre o que poderia ser feito e como eu finalmente adquiri minha identidade de cura e sua relação com o universo em geral.

Eu sou uma igqirha formada de pleno direito, professora, enfermeira e pastora. Exerço Psicologia clínica e fundei uma igreja profetizada, um sonho que eu tive em 2001. Sou também uma das fundadoras de um projeto comunitário para o desenvolvimento rural da minha vila. Todas essas conquistas me foram mostradas em sonhos e eu segue meus sonhos sob circunstâncias muito desafiadoras. Venho de uma família com uma rica linhagem de curadores tanto pelo lado paterno quanto pelo materno, e ainda assim ambos se tornaram cristãos convertidos convictos e ignoraram os ritos culturais. Tornar-se uma curadora não foi fácil.

Palavras-chave: estágios de treinamento, igqirha, Xhosa, ukuthwasa, iphehlo, vocação, identidades de cura. 


\section{INTRODUCTION}

The Xhosa healers qualify for healing identities through an inborn calling - ubizo. A fully fledged pedagogical cultural training under a well qualified and experienced healer as a mentor. The training is lead, guided and informed by ancestral wisdom and conscience through guiding dreams called amathongo. Nobody can wake up one day and say II want to be a healer'. It is inborn gift and ancestors are believed to be involved in the election as well as selection of the incumbent. Qualifying as a healer bestows one with extra ordinary powers spiritually and socially, as socio-cultural gender boundaries are cut. Often, it is perceived as a woman's gift and even men undergoing the training use a woman's dress code even during ritual perfomance. I request the readers of this narrative to kindly visit and read more about the in depth personal journey and life stories of other traditional healers who successfully embarked on this spiritual long and complex journey. The book is called, UKUTHWASA INITIATION OF AMAGQIRHA...(MLISA, and NEL, 2010). The book also include key themes such as : the interface between African religions and Christianity, the healing effects of theories used to critical discuss ukuthwasa in dirvese pespections to allow deeper insights into understnading its value in life. In this narrative, only brief discusions can be made from a 20 years persued journey coupled with experiential reflections.

\section{THE PEDAGOGICAL STRUCTURE OF THE UKUTHWASA TRAINING}

The training involves a number of continous stages and that could not be easily differentiated unless, one is well informed. The curriculum is flexible and directed mostly by dreams and cultural value systems. However, like in any pedagogic context, knowledge transfer takes a variety of teaching methodologies as well as continued monitoring and evaluation processes. Condonation depends on full mastering of any stage and at the end a graduation ceremony that carries a particular regalia relevant to the iphehlo (particular cultural training school) is offered. Various schools conducts their training differently as well as their uniform and regalia, however, common among all are competencies to qualify for, ethical conduct and professional standards to adhere to. The narrative concentrate on the Komanisi, iphehlo cultural training school. It is critical to note that it is a training like any other professional training with entry level requirements, pedagogical instructions, criteria for assessment and condonation including graduation and internship after graduation. The challenge is, its orality, a challenge that is being managed currently. This therefore sets this training as valid and as official like any professional training program. Theorectical perspectives used in the training 
I am an igqirha (healer): phenomenological and experiential spiritual journey towards healing identity construction

are a combination of both African and Western training and in my experiences it uses more particularly a systematic family theory, as clients or patients are diagnosed and treated fully in the realistic not idealistic manner as allopathic healing interventions do. All aspects of life as World Health Organization (WHO), (1995) specifies are always included in the therapeutic regime such as:emotional and psychological, spiritual, physicial,and social aspects. Above all, work place, family, lost property, future and past challenges are always included, hence the training could be referred to as Problem Based Learning method.

The graduates qualify not only at spiritual level but also emotional maturation should be clearly reached before graduation. At the end the training qualifies graduates as multi-skilled healers without borders. These are differentiated from herbalists whose skills and gifts are acquired by generic knowledge of medicinal plants and training under an experienced herbalist or herbalist training programs as these are easily available and open to all. The most critical ethical codes are, honesty, self -respect and that of others, humility and strict adherence to peaceful and healing strategies with no harm to any human being. The ancestors provide immediate guidance and through the ancestors the healer seeks Supernatural guidance from the Creator and universe. Hence, umbilini (intuition) becomes a central tool in the divination system (MLISA, 2013 \& MLISA and NEL, 2014). Consequently, that is why their bodies and senses work as a barometer to sense the universe's equilibrium and reach their folk rich collective unconscious that enables them to be able to see, hear and predict the future and reflect on the past using all their five senses: sight, hearing, smell and taste. That is why they can directly foretell the challenges and life status of their clients, and are not told by their clients like in the case of their counterparts, medical doctors, pastors and other western trained psychotherapists. Generally, a Xhosa trained healer does not use bone oracle as in other African cultures especially the Thembu and Mpondomise healers unless trained outside their cultural schools of training. Bible is used by those who end up in the sycnretism on traditional religion and Chrisitianity and are called faith healers.

To understand the ontology and cosmology of ukuthwasa among amaXhosa demands a brief summary on the context of its origins, acrocities and turbulence experienced during the journey as well as how it evolved to what it is in the twenty -first century. The historical background could be best summarized as follows: 


\section{PRE-COLONIAL ERA, BEFORE THE 17TH CENTRURY}

Critical challenges addressed by literature during this era, are: the myth that South African history only started with the arrival of Portuguese Settlers at the Cape in 1497 (WILSON \& THOMPSON, 1969 and GILIOMEE \& MBENGA, 2007). Yet, existing evidence reveal that amaXhosa inhabitat the Eastern Cape before the seventh century, and this has been largely ignored (MAGUBANE, 2000; MABONA, 2004 and GILIOMEE \& MBENGA, 2007), while the history of their origins from the East remains only an assumption. In addition, the orality of the Xhosa history remains a challenge. Thus, the above factors contributed to the marginalisation of the relevant history of amaXhosa in the Eastern Cape, to the extent that what has been written tends to be fragmented. It does not provide events systematically and epistemic evidence of the life of the amaXhosa (WILSON \& THOMPSON, 1969 and MABONA, 2004).

However, the little evidence in literature is enough to convince us that the Xhosa have traditional healing divination systems, their strong belief in ancestors, rich solidarity and collectivism among them hence an idion: umntu ngumntu ngabantu (a man is a being because of the others). They believed in the ancestors guidance, leadership and support. Their life style was abundantly governed by Ubuntu principles, something that is lost today. The breakdown in their cultural traditions, values and system are correctly blamed to the colonization era and other systematic social factors. The diverse cultural systems within the Xhosa culture should be considered. AmaXhosa at the stage were highly influenced by the Khoisan, hottentots and Fingos who fled from Shaka wars in KwaZulu Natal. AmaXhosa heterogenic cultural system alone is a challenge. Their own cultural divisions are: Thembus; Bhaca, Hlubi, Bomvane, Gcaleka, Ngqika, Mpondo. The diversified Xhosa culture on its own has affected the structure and hermenutical interpretations of their various religious practices, beliefsystems and value systems which differ at regionally basis, hence in this discussion, focus is on Komanisi (mixture of all) practices. Xhosas were rich and independent successful farmers who enjoyed life as it comes until the cattle killing crisis in the next era.

\section{COLONIAL ERA AND APARTHEID SYSTEM, 17TH TO 20TH CENTURY}

Out of the 9 provinces in South Africa, Eastern cape was the most colonized province and results of such are evident to this day. Transformation to the traditional lifestyles and spirituality could be blamed to the contact of the Xhosa with the colonizer, epidemic diseases that killed millions of people, boer wars and many other events that 
confronted them (PEIRES, 2003; WALKER, 1990; HUNTER, 1979; PAUW, 1975). KHABELA (1996, p.5), in his book The Struggles of the Gods summarises the impact of this era as follows:

The wars of conquest against the Xhosa form an ambiguous nucleus of colonial rule combined with missionary enterprise. The systematic conquest and subjugation of amaXhosa took three significant stages. The first stage climaxed in the war of Hintsa. During this time, the amaXhosa were driven beyond the Keiskamma River. The second stage is climaxed by the war of Mlanjeni, a major effort to seize more of the land of amaXhosa. AmaXhosa were expelled from the frontier and restricted to segregated locations. The third stage was the fall of the Xhosa nation, a dramatic event that led amaXhosa to make a drastically religious protest against their ancestors by embarking on widespread cattle killing in the wake of the Nongqause Prophecy in 1857.( italization and emphasis mine). This led to mushrooming of faith healers.

Faith healing erupted as an alternative to ukuthwasa and three inital prophets of the time could be mentioned: Nontetha, Ntsikana and Mgijima (HASTING, 1996; EDGAR \& SAPIRE, 2000). As ukuthwasa was negatively perceived faith-healing evolved as a charismatic religion more closely related to Christianity. Therefore, the influence of Christianity and Islamic religion superseded the African cosmology. Pentecostal and Zionist Churches mushroomed and ukuthwasa remained a myth, heathenism, paganism and mostly an underground practice loaded with law sanctions and court punishments. Ukuthwasa evolved later on.

\section{BANTU HOMELAND SYSTEM}

Nothing much changed during this period. However, ukuthwasa practice gradually evolved and could be practised publicly with a limited respect from both Christians and the educated elites, with some Christians also undergoing the training. Some Christians would consult with both herbalists (amaxhwele) and healers although nicodemously and at night as it was still an embarassment to be seen consulting these healers instead of medical or western trained psychotherapist. However, once all western means could not assist, a traditional healer was an option (MABUNDA, 2004). At the same time, herbalists were in practice and easily marketing their services. Ultimately ukuthwasa was seen as a thing for illeterates, no longer a 
I am an igqirha (healer): phenomenological and experiential spiritual journey towards healing identity construction

calling. However, it survived irrespective of all odds. The derogative name, of witch -doctor ${ }^{2}$ prevailed not that healers were witches but because white researchers and writers perceived healers as witches because Chiefs exploited them by using them to 'smell the witches' and for sorcery.. The healing opponent was not higly popularized. Education system and Christianity continued to ridicule the gift of ukuthwasa and many Christians were removed from the church roll if they underwent the training.

\section{AMAXHOSA AND THE UNDESRTANDING OF GOD}

The Xhosas always believed that there is a Supreme being up there at the skies and had power to create everything and wanted His people to leave in peace, hence the principle of Ubuntu. The Supreme power was called Qamata- the Creator and the first being.

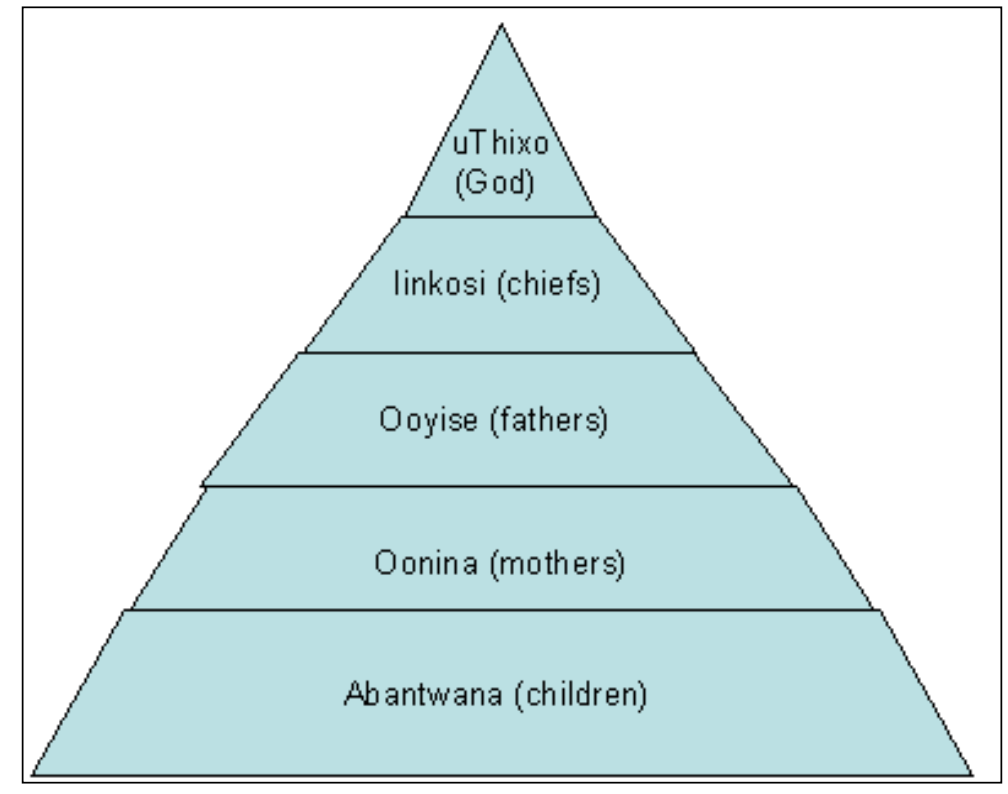

Figurel: The hierarchical position of ancestors in the amaXhosa family structure

The pyramid shows that the Creator, Qamata , Thixo (God) is the supreme power. The chiefs and simultaneously healers are viewed as advocates of the people through ancestors to God. Healers are also called : abahlekazi (cheifs) because of their powersful spiritual role and ancestral conscience and wisdom they possess (SOGA, 1931). This belief still applies.

Many African scholars argue about African religions and abundance of spirits and deities. Among the Xhosa, there are no deities and to talk about 'spirits' is viewed negatively as ancestors are perceived as human hence, they can experience phyiscally and emotionally

2 The term 'witch' in South Africa is perceived in negative ways and suggests, harming others. 
even after death (MLISA and NEL, 2010). They are not represented by any material or ritual element as in Yoruba and other African cultures. They show themselves as 'human' even in dreams and visions. However, animal totems are very important as ancestral powers are associated with such animals like the snake ' majola', which among the Majola clanships it is respected and is its visit in the household is perceived as bringing a critical message or luck. Other than animal totems, no other structure is used to resemble ancestors or Qamata (God). This then clearly indicates the diversity of the African diaspora spiritual journeys, interpretations and beliefsystem. In my view, all what is needed is to invite more narratives, discursive dialogues and at the end, acknowledgement, respect and a non -judgemental and unconditional acceptance of our African differences, and to love each other as 'we are', a respectful and dignified 'Spectre of the other'.

\section{POST 1994, THE DEMOCRATIC INDEPENDENCE ERA AND ITS PROMISES TO THE HEALER}

Drastic political changes were observed by healers as the political environment favoured their existence, valuable role they play in the communities. Many platforms were created including the Bill of Traditional Healers passed in 2004 and the Traditional Health Practitioners Act in 2007. At last not only the political sphere changed, Christianity boundaries became permeable and followers could accept their calling with no fears and tensions (except in few churches such as like Seventh Day, there is still resistance, however, some followers just follow their call and leave the church). Currently, the Traditional Health Practitioners do get recognition even in public health sytem as seriously advocated by WHO. The challenges are still there, such as legal professionalization and formal (to meet the influencial western popular still dominating values) standardized training to be officially enrolled in the Health Professional Council like their professional counterpaths. They are officially called Traditional Health Practitioners and could be eligible to writing sick leave certificates and use medical aid system.

\section{THE SUMMARY OF THE TRAING STAGES.}

The training evolves through seven stages including sub-stages and diffusion of certain stages at certain occasions. For full in depth insight to these stages and specific images illuminating relevant images per stage, kindly consult with MLISA and Nel, (2010). 


\section{FIRST STAGE: PREDICTION STAGE OF A CHOSEN IGQIRHA}

The person is chosen as a healer by her ancestors at conception by a process called ukuqajwa (to be chosen). There is no apparent chronology as to which child will be chosen. However, experience and observation in my twenty years as a fully fledged healer now is that often the first-born or the last-born gets chosen, although at times any child may be chosen. Experiential narratives of amagqirha reveal that indications that a person has ubizo, (the calling) to thwasa can be identified as early as at birth (HIRST, 2000).

\section{SECOND STAGE: MANIFESTATION OF SIGNS TO INDICATE THE UBIZO [CALLING]}

The first stage signs persists and often are now mixed with some sicknesses that may not be treated successfully with any allopathic treatments. Various illnesses and perhaps seeing, shades, hearing voices and very alarming dreams, others see snakes as in Hirst, 2000 and 2005), clanship animal totems, and many others. This is often diagnosed as pathology by wetsern trained doctors and priests at church; and at times ultimately attracts unnecessary admission in a mental hospital. At this stage, some families would start the process by seeking counsel with igqirha (healer) to verify or confirm what is happening. It is well known tradition to resemble ukuthwasa with sickness as it is often revealed through a series of syndrome signs and symptoms (HIRST, 2000; MLISA and NEL, 2010, MQOTSI, 1957) or crises. Hence, amaXhosa refer it to ingulo emhlophe (white sickness) (DWANE, 1995) or simple, ingulo (sickness).

\section{THIRD STAGE: THE STAGE OF INTENSE AFFLICTIONS}

At this stage the stage crises and sickness intensify and a family is forced to do something. That is why most perceive it as first stage (HAMMOND-TOOKE, 1989; HIRST, 2000; BROSTER, 1981 and MQOTSI, 1957). Verification and confirmation of a need to start the journey of ukuthwasa becomes more apparent and in most becomes a last straw. After confirmation, the training often starts immediately or later on depending on the socioeconomic status of the family, as the processes is expensive. It was to me. No church prayers or doctors treament brings a cure, except cultural training. It is the sickness of the ancestors a pre-requisite to be trained as igqirha. 
I am an igqirha (healer): phenomenological and experiential spiritual journey towards healing identity construction

\section{FOURTH STAGE: CONFUSION, RESISTANCE AND/OR ACCEPTANCE}

This stage also forms extended part of the screening process as means of verifying the presence of the calling. The following sequence was apparent as the participants related their stories. My experiences are that, these stages may not follow this sequence, and will always be experienced because we have already been discriminated by Christianity and education all against our traditional healing systems and values. This may not be a specific stage but continuous personal conflict that is revealed in almost all the stages as it is caused by fears of the unknown and by the tuberlance of crises involved. It is critical to read these stages as they are continuous feelings leading to crisis and ambivalence that could lead to an initiate not completing the training, a dangerous move not only to the initiate but whole family. This is where most people get stuck to one stage with fears to proceed.

\section{FIFTH STAGE: UKUVUMA UKUFA: ACCEPTANCE OF THE CALLING}

The actual training begins. This stage involves a series of activities that could be categorised into sub-stages: the sub-stage of ukungqawa (beading) and that of ukungqwamba (wearing goatskins), with two ritual activities: cleansing and acceptance during each sub-stage. This is a first stage of the initiation process as igqirha. Verification has been finalized and a prospective initiate is ready to begin a long cultural spiritual journey. Most respondent questioned me both in Brazil and Vienna Jungian Conference about why the training takes so long (5 years and more) and what happens during the training and how does one cope. The length and duration of the training explains it all. Common in all these substages stages are: perfomance of variety of cultural rituals for cleansing, purification, intensfication of ties between ancestors and the initiate, restrictions to be observed and disciplinary and ethical conditions to be observed by the initiate. In African lifestyles sacrifices are not perceived as a means of repentance, but a means of cleansing and purifying the physical body to release the spiritual element that seeks spiritual repentance.

\section{SIXTH STAGE: UKUPHUMA}

This is the last stage of the intensive training that prepares umkhwetha to be a fully fledged healer. It proceeds to graduation. It consists of four ritual activities: 1) ukutshotsha (to be ragged); 2) ukugongqa (to retreat); 3) ukubaleka enkundleni (to run); and 4) ukubekwa enkundleni (to be seated at the open space in front of the kraal). This last activity is the graduation. At this stage umkhwetha graduates to become a fully fledged 
diviner and it is called ukuphuma/ukubuya (getting out/coming back); thereafter, it is ukuphinda indlela (to go back to the trainer for advanced training and practice), resembling an internship stage. By new dress code the graduate is brought back to normal life again, bust as a new person (german skirts), amadaki. Then the person has completed the crucial basic training of a fully fledged igqirha. However, in Komanisi iphehlo ikrwala is expected to ukuphinda indlela - to return (to the trainer, igqirha) to learn the deep secrets of ukuthwasisa (to train those who thwasa) only shared with igqirha. The duration of the sixth stage, including all the activities, is almost five days.

\section{SEVENTH STAGE: UKUPHINDA INDLELA}

The last stage is ukuphinda indlela (to return to the trainer), or internship stage. During this stage, ikrwala learns about secrets not taught to abakhwetha during the training. She also attends and witnesses the performance of ritual ceremonies of those restricted to abakhwetha. Many people refuse to do the internship because they feel that the process has lasted long enough and they do not wish to go back again. I did it because, I kept having dreams that I must do it. During the internship, the trainer prepares iimpondo (horns) from all the goats that have been slaughtered during the training. Inside the horns are various mixed pounded herbs used for various reasons including ukuqinisa umkhwetha (to strengthen the initiate) when ikrwala leads a ceremony for graduation. Most of the herbs used during all the stages from umgongqo to graduation day are always treated as a secret. This stage is the time to learn them. That ensures that ikrwala (the graduate) is forced to go back to her trainer at some stage. Again, a person is expected to stay a few days during each visit, but the duration depends on the mood and the relationship between igqirha (mentor) and ikrwala (graduate).

From my observations, reflections and experiences, the evolutional nature of ukuthwasa and its future, which is still gradually unfolding as TURNER (1968 and 1969) suggests, show that historical periods can be liminal and transitional times. That is so because the past of ukuthwasa has changed from being perceived by the Church as a pagan or heathen practice to be considered a reality that is acknowledged. The rituals in each stage therefore form part of resolving the conflict situation created by afflictions, separation anxiety, identity crisis and a continued feeling of ambiguity - the 'betwixt and between'. Thus, ukuthwasa can be seen as a transformative initiation that involves a cycle (birth, maturity, incarnation, cleansing and burial) of rites of passage, and in that way may be perceived to share elements of rites of 
I am an igqirha (healer): phenomenological and experiential spiritual journey towards healing identity construction

passage, since it marks the transition of a person from various transitory stages and a change of social status (BATES \& ELLIOT, 2003).

Healers represent liminal beings, because they are out of place and are different from the public at large. With their intuitive skills they threaten the orderly conceptualisation of society. Because they are mysterious, powerful, and liminal beings as Turner suggests, they can be sources of renewal, innovation and creativity. stage often creates serious tension and friction amongst certain amagqirha. This could be related to the separation anxiety that often occurs when a child has to leave the parent to stay or work away from home. Such tensions may or may not be resolved. At the end of this stage, I felt my antithetical body that was struggling to accommodate the traditional and Christian world has been transformed into a new constructed 'self', that of a healer with a holistic view of one universal world and I being igqirha. It felt like being a hero, and a leader of the nation. Nature has inflicted, nature has reconciled, and she is now igqirha. Through her participation and incarnation in all these rituals she receives a spontaneous skill to connect with the abundant supernatural knowledge and wisdom.

\section{DISCUSSION}

It is becoming more clear that, irrespective of diverse cultures, languages and differences in religious belief systems, values, ritual performances, interpretations and symbolism used, I have experienced common reactions and responses from all. That is great, as it reveals one truth, not just the Pan Africanism but universal 'oneness and uniqueness within us, between us and others. Ancestral linkages are interlinked by the universe and beyond any man-made dogmas and cultural diversity. We can all speak in different tongues, but healing sphere knows no boundaries. I great and respect all ancestors around the globe and their sacred places, may their abundant blessing keep us all in one and the chain created in Brazil to remain a 'sign of visible and respected Pan African religious oneness among all of us including the enemy, our colonizers. Let our continued dialogues and sharing of our narratives to be a healing 'therapy' for the past wounds. Camagu!

KLEINHEMPEL (2018) alludes to the cosmology of Umbanda as one of the African religions that had to adapt to various changing environments in a process which continues to this day. RUFFIN (2016) argues the juxtaposed gender balances in the African 
I am an igqirha (healer): phenomenological and experiential spiritual journey towards healing identity construction

indigenous systems and effects of slave trade in Brazil and Cuba, in Yoruba religion and practices. Currently, Umbanda is even breaking the chains of gender boundaries and women are gradually becoming leaders in rituals only men were accepted. This means African religions are tools to create a conducive environment for integrative therapeutic religious and spiritual tolerance among 'us, and others', a positive 'spectre of the other' through relevant 'love, passion and respect for each other."

The discussion reflects to all motivating requests as already alluded to about the cosmology of ukuthwasa (or calling and reality of the gift of healing and its role to the self, family and community at large). From my childhood, I was a house of dreams (CUMES, 2004) and my dreams always worked as a warning, protective skill as well as prediction of the future. I believe in my dreams and nothing at this stage could convince me otherwise. I was thrilled by educational qualifications through western brainwashing, but from my experiences I can still stand firm and do not deny my identity as a healer not now not tomorrow. In all conferences I have made presentations, the following are some of the evidence that spiritual and intuive gifts are able to connect me and merges me with the ancestral worlds of all people I meet. In the two presentations in Brazil (2018) at the Jeus de Fora Conference, this is part of the feedback I received from various respondents:

Respondent A: "your presentation touched me and I cried because it was as if, you were also referring to my own feelings. At times I get afraid because I think I am losing myself"

Respondent B: "how long does it take to get trained? I have started with my 'master' (mentor/trainer in Xhosa), but there are tensions and I have stopped".

Other respondents: "how does it feel when you talk about yourself in public so bold and self confident?"

Other reactions: (i) Professor Babalawô Ivanir dos Santos, during the media interview at the reception hall in Brazil, calls me from behind and unawares and says "can you please come in front and pray for us?" The whispers of the ancestors once again revealed intuitive spiritual linkages and oneness, breaking the boundaries of regionality and culture.

(ii) visitation to a sacred place, the following morning with the same professors and other conference participnats, provided an evidence of the permeability of spiritual bodies and sensitivity among those with a gift. One lady from the congregation comes to me hugs 
I am an igqirha (healer): phenomenological and experiential spiritual journey towards healing identity construction

me, cries, and we both simultaneously experience a strong feeling of intuitive connection, joy, sadness, passion and mixed feelings became prominent. The unexplainable connection only expressed by physical touch and emotional gestures. The universe connected us but expressions were hard due to language barriers. How does this bonding happens if ancestral spiritual linkages are not in play?

Presentations like the one I presented recently at the IAAP international Jungian conference in Vienna, ( https://iaap.org; https://bit.ly/iaap-cloud, 2019) provides another evidence. We were four presenters and I was the third to present. Immediately after my presentation a conference hall with more than 1000 (no exagerations, exhibits a standing ovation as expression of their passion, reception and another spiritual intuitive linkage) participants suddenly stands up clapping hands, row by row and all were up. Others calling "hallelujah;Amen!!" others crying. The time for the next presenters was delayed by the emotional moment and the chair person tried to calm the atmonsphere. I had a range of individual sessions after the plenary session, and right through until I left. It was good that our plenary was on the last day of the conference. The word spread to the extent that after 3 days, I had to present the same presentation at a Jungian Institute, in Zurich. It was evident, they were waiting for me. Did I meet different questions from the ones in Brazil and South Africa, no! People are tired of pure academic research results and sermons at church from the same Bible misused and misintepreted to disown people their identies. They are interested in evidence-based life hermenutics and evidence based coping life personal narratives that talks to their life realities versus the idealistic life.

The training stages are long complex and full of life crises and need discipline, humility, resilience and belief to the Supreme powers of the Creator, which the Xhosa and most African religions do not deny no matter what diverse interpretations are given or symbolism used or names given to the Creator of all and universe powers. The mythology involved will always bear different interpretations. Supporting this undeniable evidence are the following responses:

CHINWEIZU's (1987, p.73) suggestion towards resolving African problems may be supported when he states: "Shift intellectual gear from what Europe has done to us (how colonization brainwashed us about our culture), to what we are doing to ourselves (how we undermine our own roots and identities by looking down on our culture), and to what we must do for ourselves in order to get out of our condition (how we may reclaim our own 
I am an igqirha (healer): phenomenological and experiential spiritual journey towards healing identity construction

traditional cultural values, embrace them and reclaim our authentic identities). 3 The strange and weird fears we have about our cultural rituals, our identities and acceptance of 'who we are' are from the Eurocentric socialization ideologies including Christianity and western system both viewing our culture is inferior, pagan and heathen.

MUDIMBE suggests the best strategy to resolve the long-standing debate of the interface between African religions and Christianity as to consider the condition of the existence of African gnosis and of its best sign, anthropology, as both a challenge and a promise. Perhaps the gnosis will make sense if seen as a result of two processes: first, a permanent re-evaluation of the limits of anthropology's knowledge in order to transform it into more credible anthropou-logos, that is a discourse on a human being; and second, an examination of its own historicity (MUDIMBE, 1988:186). As Professor Jacob Olupona, respected and noted scholar of indigenous African religions clearly endorsed the need of historical background in any study done and how this should be emphasized to our students (personal feedback after my presentation). History is a best teacher to show ontology and evolution of our religions and challenges it went through. It is a tool for survival and evolution. Once we are aware of our cultural roots we stand without fears and are bold to share our identities with no shame and apology to anybody. We shake the shackles and bondages of intended slavery and become 'cultural born-again'.

ADOGBO (2005) suggests a macro-theory that could be used by those interested in exploring religious beliefs or value systems of other cultures (read more in ADOGBO, 2005, pp. 81-82). He prioritises the following areas as focus of research: 1) $A$ thematic approach which focuses on the concepts held by that particular ethnic group on spirits, spirits being and spirit forces, rituals and ritual symbolism; 2) A descriptive approach which gives an exposition of the spirit being, noting inter alia their names, concepts, etc., with all those being discussed within the context of the people's cosmologies and practices; 3) A historical contextualisation of symbolic forms noting its evolution or transformation over years; and finally 4) Research to focus on beliefs and practices of the people with a view to establishing a general religious character as expression of sacred realities or otherwise. This is supportive of the call from our legend General Ishola Williams of Lagos at our conference plenary, about the compilation and production of Indigenous Sacred Texts in African Languages. What are we waiting for?

\footnotetext{
3 Statements in brackets are that of the researcher.
} 
I support Erdtsieck's experiences amongst the Tanzanian spirit healers and her general conclusions in particular: No matter what science does to prove the existence or nonexistence of the spirits, one thing is undeniable, namely that for many people across the nations and cultures iminyanya (ancestors) are a reality that must be reckoned with, whether it is clear, blurred, or confused reality. The belief in ancestors and the nature of spiritual powers, demands and deserves academic attention because it is not a means to safeguard the knowledge of traditional medicine and healing, it is also a means to enhance the cross of boundaries between the conscious and the unconscious, the living and the dead, the present and the past, the old and the new and the known and the unknown. Ignoring these healers is to ignore their cultural identities. (ERDTSIECK, 2003, p.386). The visits to the sacred places and the annual inauguration ceremonies to revive the Pan African Religions histories and legacies is evidence enough to strengthen those who still have cold feet to embark on their spiritual journeys. It also shows how the predecessors coped and adapt against all odds.

In conclusion, the psychology expression that says, "until you know who you are, you would never know how to become and who to become" (unkown) is true beacuse identity construction and negotiation is a complex journey and could easily inflict the seeker with various stypes of wounds, hence Carl Jung views the journey towards inviduation as a wounded process, and those embarking on it as 'wounded healers'. It is good the expeience crisis and wounds so that in turn, you are able to identify the wounded and heal them [CARL JUNG, 1990]. African cultures to pride themselves as the very Eurocentric and North Atlantic cultures have reversed their oppressions and have identified value in our cultures. LAING, (1989, pp. 79-81) supports this view:

Western philosophy, culture, and medicine view illness as bad, something to get rid of as quickly as possible. It is seen as something invasive: a virus, bacillus, etc., are regarded as an alien process that incapacitates paralyses and destroys the body internally. It is viewed as an unnatural state of affairs that should be suppressed by every conceivable means. On the other hand, Asian and tribal cultures view illness and suffering as processes of physical and psychic transformation (LAING, 1989, p.80). They itperceive it as psychic and physical suffering intended to alter consciousness and as forces and mechanisms of transformation and self-healing. Death is perceived as a way of regenerating and recovering from one's earthly existence. Hence, spiritual journeys are transcedental journeys. 
Lessons should be learnt from the colonized South Africa and ontology or ukuthwasa to how it revolved to be today. PRETORIUS (2004, pp. 545-555) describes the current situation of traditional healing in South Africa as that of hope to its practitioners as well as that of mixed feelings to some of the healer's counterparts. For instance, PRETORIUS (2004, p.548), FRIEDSON (1970, p.232) and ASHTON (1943, p.14) reveal the different attitudes of the medical practitioners and other professionals towards amagqirha and that of change as some of healers are co-opted into certain medical treatment programmes such as HIV / AIDS training programmes, cancer programmes and others. Together with the Jungian psychologists and analysts in South Africa, we are pioneers of an integrative psychotherapy program across cultures, called "rain bow therapy". Although it is still at its neophyte milestone, the positive reception of this presentation in august, 2019, in Vienna, is promising. Perhaps, this is a call to the Institutions of Theology as to what means are being done to assist them towards best possible integrated syncretic strategies and professionally managed religious and spiritual practices. It can be done with respect and unconditional acceptance. I praise those who have started. May the blessings of the Creator embrace you with unfading light.

Without doubt, all facets of my identity are complete, well-balanced and I feel an actualised person. "I am igqirha, a prophet and spiritual healer more closer to my Creator, mother earth and the universe. I fully agree with BLAKELY \& VAN BEEK, (1985); VAN BINSBERGEN (2003); PEEK (1991) and WINKELMAN \& PEEK (2004) and MASOGA, (2001), a fully-fledged trained traditional healer, academic and scholar and a professor, dean of a faculty, that amagqirha divination system is dynamic, because Africans shower new problems and options with fresh meaning, firmly tying emergent orders into the previous ones. Their religion has proven to be flexible, universal, pluralistic, non-dogmatic and action-oriented, and combines ideological ambiguity with a 'bricolage' of old elements into new patterns Camagu! (Amen).

\section{REFERENCES}

ADOGBO, MP., Methodological problems in the study of African traditional religions. Journal of Theology for Southern Africa vol. 122, July 2005 (pp. 76-83).

ASHTON, EH., Medicine, magic and sorcery among the Southern Sotho. Cape Town: University of Cape Town.1943

BATES, DG., \& ELLIOT, MF., Rites of passage from cultural anthropology. 3rd edition. United States of America: Pearson Education Inc. 2003. 
BLAKELY, TD., VAN BEEK, WEA., \& THOMSON, DLT., Religion in Africa: experience \& expression. London: James Currey 1985. (pp,160-181).

BROSTER, JA., Amagqirha: religion, magic, and medicine in Transkei. South Africa: Via Africa Ltd. 1981.

CHINWEIZU, J. Decolonizing the African Mind. Nigeria: Pero Press.1987.

CUMES, DM., A surgeon's odyssey into the spirit world of African healing. Claremont: New Africa Books. 2004.

DWANE, S. Ingulo emhlophe in Xhosa society. South Africa: Ubuntu Publication 1998.

EDGAR, RR. \& SAPIRE, H. African apocalypse: The story of Nontetha Nkwenkwe, A twentieth-century South African prophet. Johannesburg: Witwatersrand University Press.2000.

ERDTSIECK, Jessie. In the spirit of Uganga: inspired healing and healership in Tanzania. Amsterdam: AGIDS. 2003.

FRIEDSON, E. Professional dominance: the social structure of medical care. New York: Atherton Press.1970.

GILIOMEE, H., \& MBENGA, B., New history of South Africa. Cape Town: Tafelberg.2007.

HAMMOND-TOOKE, D.Rituals and medicines. Johannesburg: AD Donker Publishers.1989.

HASTING, A. The Church in Africa: 1450-1950. Oxford: Clarendon Press.1996.

HIRST, M.M. Root, dream and myth: the use of the oneirogenic plant silene Ccpensis among the Xhosa of South Africa. Journal of Psychoactive Plants and Compounds. New Series Vol, 4 , 2000 (pp,121-149).

Dreams and Medicines: The Perspective of Xhosa Diviners and Novices in the Eastern Cape, South Africa. Indo-Pacific Journal of Phenomenology Vol, 5(2), 2005. (pp, 1-22).

HUNTER, Monica; Reaction to conquest: effects of contact with Europeans on the Pondo of South Africa. Abridged paperback edition. Cape Town: David Phillip 1979.

JUNG, Carl, Gustav. The archetypes and the collective unconscious. New York: Princeton University Press.1990.

KHABELA, MG. The struggles of the gods. A study in Christianity and African culture. Alice: Lovedale Press.1996.

KLEINHEMPEL,Ullrich,R., Retrieving African Traditional Religion from the Fringes-Umbanda and the Brazilian Traditions as a Source. Journal for the study of the Religions of Africa and its Diaspora,Vol.4(1) December 2018 (pp.67-81). 
LAING, R.D. Transcendental experience in relation to religion and psychoses. In Grof S \& Grof CG (eds). 1989. Spiritual emergency: when personal transformation becomes a crisis. Los Angeles: Jeremy P. Tarcher Inc. 1989.

MABONA, M. Diviners and prophets among the Xhosa (1593-1856). A study in Xhosa cultural history. Münster: Lit Verlag.

MABUNDA, MM., Perceptions of disease, illness and healing among selected black communities in the Northern Province, South Africa. Southern African Journal of Ethnology, Vol.24(1), 2004 (pp. 11-16).

MAGUBANE, P., Vanishing cultures of South Africa. Changing customs in a changing world. Alice: Fort Hare Library.2000.

MASOGA, Mogomme Alpheus., Dimensions of oracle-speech in the Near-Eastern Mediterranean, and African contexts: A contribution towards African orality. Unpublished $\mathrm{PhD}$ thesis. Bloemfontein: University of the Free State. 2001.

MLISA, LilyRose Nomfundo.,and Nel, Phillip., Ukuthwasa The Training of Xhosa Women as traditional Healers: Ukuthwasa Initiation of Amagqirha and Identity Construction. Saarbrucken: LAP LAMBERT Academic Publishing GmbH @ Co.KG. ISBN 978-3-8433-73777. 2010

Types of Umbilini (Intuition) in the "ukunyanga" (Xhosa Divination) Tradition Journal of Psychology in Africa. Vol. 23(4) 2013, 23(4), 609-614

MLISA, LilyRose Nomfundo., Intuition as divination among the Xhosa of South Africa. In Reviewing Reality. Dynamics of African Divination' by van Beek, WEA \& Peek, P (Eds), 2013, pp59-82 .Berlin, Lit Verlag.

MQOTSI, L, A study of ukuthwasa: being a syndrome recognized by the Xhosa as a qualification for being initiated as a doctor. Unpublished Master's thesis. Johannesburg: University of the Witwatersrand 1957.

MUDIMBE, VY. The invention of Africa: gnosis, philosophy and the order of knowledge. London: James Currey 1988.

PAUW, BA., Christianity and Xhosa tradition. Cape Town: Oxford University Press.1975.

PEEK, PM., African divination systems: ways of knowing. Bloomington: Indiana University Press 1991. 
I am an igqirha (healer): phenomenological and experiential spiritual journey towards healing identity construction

PEIRES, J. The dead will arise: Nongqause and the great cattle-killing of 1856-7. 2nd ed. Johannesburg. 2003.

PRETORIUS, E., Complementary/alternative and traditional health care in South Africa. In: Van Rensburg HCJ (ed). Health and Health Care in South Africa. Pretoria: Van Schaik. 2004 (pp. 506-560)

SOGA, H., (ed). The life and customs of the Xhosa. South Africa: University of Fort Hare Library. 1931.

STAUGARD, F. Traditional health care in Botswana. In: Last M \& Chavunduka GL (eds). The professionalisation of African Medicine. Manchester: Manchester University Press \& International African Institute.1986. pp. 51-86

TURNER, Victor. The drums of affliction: a study of religious processes among the Ndembu of Zambia. Oxford: Clarendon Press.1968

The ritual process. structure and anti-structure. Chicago: Aldine 1969

RUFFIN, Fayth A., Sacred Space of African Indigenous Forces of Nature: Environmental Ethics for the African Diaspora.Journal of Human Ecology. Vol. 53 (2).2016. (pp 124-134).

VAN BINSBERGEN, Wim,MJ.,Intercultural encounters: African and anthropological lessons towards a philosophy of interculturality. Munster: Lit Verlag.2003

WALKER, Cheryl, (ed). 1990. Women and Gender in Southern Africa to 1945. Cape Town: D. Philip. 1990. pp. 1-32 and 168-196.

WILSON, M, \& THOMPSON, L (eds). 1969. The Oxford History of South Africa, Volume 1. London: Oxford University Press 1969

WINKELMAN \& PEEK, PM., (eds). Divination and healing: potent vision. Tuscon: University of Arizona Press.2004.

WORLD HEALTH ORGANIZATION (The). Traditional practitioners as primary health care workers. Geneva: World Health Organization.1995. 